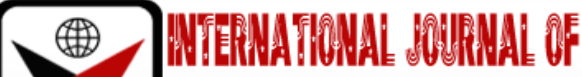

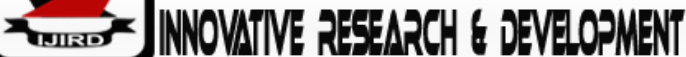

ISSN 2278 - 0211 (Online)

\section{Factors Influencing Sustainability of Rural Community Development Projects in Kilungu Sub-County, Makueni County, Kenya}

Jane Kailu Thomas
Project Manager, Department of Mission Development
Our Lady of Charity of the Good Shepherd, Kenya
Timothy Maitho
Professor, Department of Public Health, Phamacology and Toxicology
University of Nairobi, Kenya

\begin{abstract}
:
The challenge facing rural community development projects is lack of sustainability after Donor phase out or before project completion. Community development projects have been executed in rural areas in order to improve livelihoods of people. However, projects often do not meet the intended objectives, despite huge finances spent on the projects. The project beneficiaries may not get benefits, value of involvement and ownership of project. It is sustainability which determines project success and failure of community projects. The study Sought to determine social and management factors influencing sustainability of rural community development projects inKilungu SubCounty of Makueni County. The study employed a descriptive research design and target population included project beneficiaries, managers and management committee members. A sample size of 210 respondents was selected using simple random sampling technique. Questionnaires and interview schedules were used for data collection. Data was analyzed using Statistical Package for Social Sciencesand data was presented using Tables and prose. The results on social factors showed 58\% and 56\% of respondents agreed gender and education had high influence on sustainability of community development projects while 56.7\% strongly disagreed that marital status influenced sustainability of community projects. The findings on management factors showed that $66.7 \%$ of respondents had management knowledge and skills to enhance sustainability. However, 53\% of respondents indicated that people who were appointed as managers of projects were not competent. The $48.7 \%$ of respondents agreed that organizational structure helps in division of activities into manageable units. It was concluded that social and Management factors influence sustainability of rural community projects if the factors were integrated in the project cycle. It was recommended that the two factors should be implemented in the sustainability of community projects. The results are beneficial to Government officials, Non-Governmental Organizations and Managers.
\end{abstract}

Keywords: Factors, sustainability, community development projects, Kenya

\section{Introduction}

\subsection{Background to the Study}

Sustainable development is a state in which rural community development projects become self-sustaining and development projects can survive without relying on support from donors. These projects also address needs of the community and improve living standards of people. To address cause of poverty and to promote universal need for development, the United Nations Forum for Sustainable Development (2015) outlined new sustainable development goals and sustainable agenda. United Nations Development Programmes (UNDP) administrator Clark (2015) noted that the agreement on sustainable development goals mark important milestones in putting the world on an inclusive and sustainable state. Clark identified and reported the following goals; 1 . End Hunger, 2. End poverty 3 . Ensure healthy lives, 4. Ensure equitable education and 5. Ensure availability and sustainability of water and sanitation management. The goals are important because they helped this research to incorporate strategies for continuity of community projects.

In Africa, sustainable development remains a challenge because of many factors which include: Poverty, drought, hunger, disease, illiteracy, and malnutrition and health problems among others.

In Uganda, organizational Director for AMREF noted that sustainability is a concern for Uganda and other parts of Africa.

He pointed out a 2009 report by the International Institute for Environment and Development which indicated a worrying trend where hundreds of millions of dollars were wasted on boreholes in rural parts of Africa because people could not maintain them. 
In Kenya, the Kenya National Profile statistics (2001) show that approximately two million people are impacted positively by community development projects. The project by the Government and Non-governmental Organizations included interventions in agriculture, water, health and education among other projects. Rural community development projects are planned for a specific period after which the funding agencies leave it to the community and people are expected to continue running the project and make them self-sustainable. However, the projects often collapse after the projects' phase-out.

Makueni County lies in the Arid and Semi -Arid Lands areas of Kenya and is characterised by high rate of poverty, low rainfall and drought. This has led to inadequate water, hunger, food shortage, malnutrition and health problems. Human activities such as farming on hill tops, charcoal burning, and sand harvesting has led to soil degradation. The effects of prolonged droughts have led the County to face water challenges and insufficient food. This situation forced Government, NGOs and other development partners to intervene in community development projects dealing with water, agriculture, health and education. The interventions are intended to reduce hunger and improve food security and also promote health and sustainable management of waterso that the community members will have access to water and improved living standard of the people. Sustainability helps communities to achieve self-reliance. Donors and Government offer services on humanitarian grounds in order to improve livelihood of the community. Therefore, the factors which can influence sustainability of the projects were addressed since sustainability is questionable in some Counties although hugefunds have been spent on the projects.

\subsection{Statement of the Problem}

Project sustainability is a critical challenge facing rural community development projects. Panda (2007) reported experience in the development sector reveals that project sustainability is a major issue despite the numerous efforts made to develop self -sustaining projects. In Kenya, billions of shillings are channelled into the community development projects especially in Arid and Semi-Arid Areasin order to improve livelihoods of the people. Unfortunately, most projects have been characterized by low level of sustainability.

\subsection{Objectives of the Study}

Theobjectives of the study were to determine influence of social and management factors in the sustainability of community development projects in Kilungu Sub County, Makueni County, Kenya.

\subsection{Significance of the Study}

The findings are useful to Non-Governmental Organizations, Government officials and project Managers because they can use information in drafting policies for sustainable development.

\section{Research Methodology}

The Research Methodologywhich wasused in the study is presented below.The study employed a descriptive research design. Kothari (2014) indicated that a descriptive research design establishes frequency at which something takes place or the relationship between the variables. It also helps to determine the characteristics of a population and present its state without manipulation of variable

The total target population for this study was 4763 respondents which included 742 respondents for water projects, 3256 for agricultural projects, 297 for education projects, 444 for health project,4 project senior managers and 20 committee members.

Sample size is a small group selected from the entire population. While sampling refers to a process of picking a number of individuals for a study in such a way that the individuals picked represents the entire population from which they were picked from (Ogula, 2009).

A sample size of 210 respondents was selected for the study by using a simple random sampling technique in order to get a representative sample for the entire population. The Sample size was determined by using Yamane Table (1973) and stratified sampling technique was used to select respondents.

The study employedProbability sampling in orderto allow inclusion of a reasonable number of respondents in the study. The non-probability sampling technique helped in the qualitative studies involving interview for in-depth information (Mugenda and Mugenda, 2014).

Content validity was used in orderto determine the validity of the instrument.Test-retest method at two different times was used to check reliability of the instrument in order to check if the results were similar (Charles, 2002).

Data was collected using structured questionnaires and interviews. Data was analyzed by using Statistical Package for Social Sciences version 20 and waspresented by using Tables and prose.

A permit from National Commission for Science, Technology and Innovation (NACOSTI) and a letter from the University of Nairobi were obtained before beginning of the study and confidentiality was observed during the study.

\section{Results}

The first Objective of the study sought to determine social factors and sustainability of community development projects. The response rate obtained in the study was $71.4 \%$ since 150 out of 210 respondents filled the questionnaires.

The study established that $56 \%$ of the respondents agreed that education is an important tool for a community development project with a mean of 4.3 .The $62.7 \%$ of the respondents agreed that education promotes dialogue, touches the human feelings and emotions in order to enable people meet their needs and encourages problem solving which makes people to be in charge of their own development. The $70 \%$ of the respondents with a mean of 4.25 agreed that Staff 
working in development projects need to have skills required to deal with women related issues in community development projects.

The other $58 \%$ of the respondentswith a mean of 4.22 agreedthat gender has high influence on sustainability of community development projects. However, $39.3 \%$ of the respondents moderately agreed that both gender were involved in the community development for sustainability. The $32.5 \%$ of respondents with a mean of 2.9 also moderately agreed that Government and other organizations should incorporate gender issues into policies and programmes in order to ensure sustainable development. The $56.7 \%$ of the respondents with a mean of 2.5 strongly disagreed that marital status influences sustainability of community development projects.

The second Objective of the study sought to assess management factors and sustainability of community development projects. The study established that managers of the projects responded adequately to the concerns of the people and they were effective as indicated by a mean of 3.25.The respondents responses on management factors which influence sustainability of the community development project show that $52 \%$ of the respondents with a mean of 4.4 agreed that managing people, their opinions and changes they requested are important in community development projects for sustainability. The $66.7 \%$ of respondents agreed that management knowledge and skills are important factors in projects in enhancing sustainability.

The other61.3\% of respondents with a mean of 4.24 agreed that planning establishes objectives and purpose of the project.The $48.7 \%$ of respondents with a mean of 4.07 agreed that organizational structure helps in the division of activities into manageable units where everyone knows who is to do what and who is responsible. It also removes confusion and conflict in the projects activities.The $48.7 \%$ of respondents with a mean of 3.7 agreed that documenting lessons learnt and best practices in weekly or monthly basis is part of the plan and it is important in monitoring and evaluation.The $29.3 \%$ of the respondents with a mean of 3.6 moderately agreedthat project managers have adequate experience in task familiarity and management.

\section{Discussion}

A discussion of the findings is presented following objectives of the study.The results on social factors in Kilungu Sub-County showed that gender is an important factor in project sustainability. This is in agreement with World Bank on Gender Equality and Sustainable Development (2014) which noted that sustainable development of projects cannot be achieved without paying attention to gender -based differences. The findings also indicate that the level of education plays a key role in sustainability of community developmentprojects. This is in agreement with election Agenda 2017 and beyond (2016) which described education as an important tool for development.

The study showed that managing people, their opinions and changes they request are important in community development projects for sustainability as it removes confusion and occasional conflicts in the project. The findings also confirmorganisation structure is an important element in the management because it gives a comprehensive picture of how the organisation functions and the different levels of authority which are accountable for effective and efficient management. This concept is also in agreement withMugutu et al (2013). However, it was noted that skilled and experienced management was required for the success of the projects.

\section{Conclusions}

The following conclusions were made from the study; - It was concluded that community development projects have positively transformed the religious practices, family and wealth in the region. It has also encouraged residents' ownerships of the community resources. Security has improved in the region due to a decrease of conflicts over natural resources. Residents have also been encouraged to conserve available natural resources, and they have gained significant knowledge and technical skills from the project. The project has integrated people from different clans, tribes and cultures in the region, promoted building of community pride and identity and facilitated upholding customs together with promoting social networks amongst residents in the region.

It was concluded that the development project managers responded effectively to concerns which were raised by the people and this method was found to be effective. The study also found that there is sufficient technical expertise to manage the project and sufficient human resource for sustaining the project and the community is satisfied with the overall management of the community development projects. The risk management is satisfactory and the management of projects has increased the alignment of development projects with host communities' priorities. The project managers have adequate experience in management and there are clear and achievable estimates in the project schedule and budget. The community based initiatives are complex and they need comprehensive management skills. It was also concluded the leadership skills of the managers are satisfactory and the advice on technical plan was made available for the project.

\section{Acknowledgement}

I wish to thank Prof. Timothy Maitho who dedicated his time during supervision and also guided me throughout the study. I wish also to acknowledge University of Nairobi Management for giving me a chance to study in the University. Lastly, I am grateful to Hilton Foundation for financial support.

\section{References}

i. AMREF, (2009), Report by the International Institute for Environment and Development.

ii. Charles, C. M. (2002).Introduction to education research (2 ${ }^{\text {nd }}$ ed.) .San Diego, Longman.

iii. Clark, H. (2015).Speeches and statements on sustainable development report. United Nations Development Programme. Washington D.C, USA. 
iv. Election agenda 2017 and beyond: Election issuefication (2016), Published by Jesuit Hakiman Centre, Nairobi.

v. Kenya National Profile Statistics (2001).

vi. Kothari, C.R. (2014). Research Methodology, New Delhi, New Age International Limited Publishers.

vii. Magutu O. P., Nyamwange O.S., Mbeche M.I, and Onsongo O.C. (2013). An introduction to Project Management. Publisher: Lelax Global Ltd. Nairobi.

viii. Mugendi and Mugenda. (2013). Research Methods. Quantitative and Qualitative Approaches, Acts Press. Nairobi, Kenya.

ix. Ogula, P.A. (2009). Research Methods. Catholic University of East Africa Publications, Nairobi.

$x$. Panda, B. (2007).Top down or bottom up? A Study of Grassroots NGOs' approach. Journal of Health Management, 9(257), 257-273.

xi. World Bank (2014), Gender Equality and Sustainable Development Report. World Bank Washington, DC 20433.

xii. Yamane, Taro. (1973). Statistics, An Introductory Analysis, (2 ${ }^{\text {nd }}$ ed.), New York, Harper and Row. 